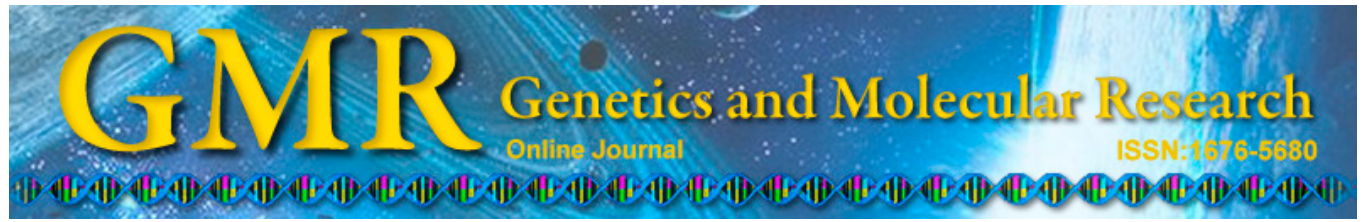

\title{
Detection of Toxoplasma gondii DNA in naturally infected sheep's milk
}

D. de Santana Rocha, R.L. de Sousa Moura, B.M. Maciel, L.A. Guimarães, H.N.S. O'dwyer, A.D. Munhoz and G.R. Albuquerque

Departamento de Ciências Agrárias e Ambientais, Universidade Estadual de Santa Cruz, Ilhéus, BA, Brazil

Corresponding author: G.R. Albuquerque

E-mail: gralbu@uesc.br

Genet. Mol. Res. 14 (3): 8658-8662 (2015)

Received January 26, 2015

Accepted April 28, 2015

Published July 31, 2015

DOI http://dx.doi.org/10.4238/2015.July.31.14

\begin{abstract}
The objective of this study was to verify whether Toxoplasma gondii is excreted in the milk of naturally infected sheep. In order to accomplish this, 275 lactating ewes were used; these were bred extensively in 17 estates distributed across nine cities. Polymerase chain reaction amplification was used to detect $T$. gondii DNA in milk samples, and the indirect immunofluorescence test was employed for the detection of anti-T. gondii IgG antibodies in the sera, with a cut-off value of 1:64. It was possible to verify the presence of the parasite DNA in $6.5 \%(18 / 275)$ of the studied animals. Anti-T. gondii antibodies were present in $41.5 \%$ of the animals studied (114/275). There was no correlation between parasite excretion in milk and the presence of IgG in $38.9 \%$ of the studied animals (7/18). The high seropositivity and the presence of parasite DNA in the milk led to the conclusion that $T$. gondii infection is present in the sheep population in southern and southwestern Bahia, and that there is a risk of the human population becoming infected due to the consumption of raw, in natura milk.
\end{abstract}

Key words: Lactation; PCR; Serology; Sheep; Toxoplasmosis 


\section{INTRODUCTION}

Toxoplasmosis is a zoonotic disease caused by the coccidian protozoan Toxoplasma gondii. The definitive hosts for the parasite consist of members of the Felidae family (Dubey, 1998), and the intermediate hosts are homeothermic animals including farm animals such as birds (de Oliveira et al., 2009), goats (Ragozo et al., 2009), cattle (Fajardo et al., 2013), pigs (Bezerra et al., 2012), and sheep (Edwards and Dubey, 2013). When humans consume raw or undercooked animal tissue, this protozoan can enter into their systems and cause infection.

In the case of sheep, infection is particularly significant as it can cause reproductive problems (Pereira-Bueno et al., 2004) ranging from fetal abnormalities and weak offspring to stillbirths and miscarriages; these are considered to be the main consequences of infection by $T$. gondii (Buxton et al., 2007). Consequently, infection in sheep results in considerable economic losses.

The excretion of $T$. gondii in milk has already been confirmed in several animal species such as goats (Vitor et al., 1991), dogs (Bresciani et al., 2001), cats (Powell et al., 2001), camels (Ishag et al., 2006), and mice (Costa and Langoni, 2010). In 2009, Jones et al. (2009) identified that the consumption of unpasteurized goat's milk posed a risk factor for $T$. gondii infection in humans. To our knowledge, only two studies have demonstrated the presence of the DNA of the parasite in sheep's milk (Fusco et al., 2007; Camossi et al., 2011). This validates the possibility of tachyzoite ingestion through consumption of in natura milk, which has been frequently observed in rural estates. Thus, the aim of this study was to ascertain whether T. gondii DNA is excreted in the milk of naturally infected sheep in southern and southwestern Bahia.

\section{MATERIAL AND METHODS}

\section{Region of study}

The study was performed between August 2012 and March 2014 and involved 275 lactating sheep from 17 rural estates in the Southwestern and Southern mesoregions of Bahia registered in the Cooperative of Sheep and Goat Producers of South Bahia (COOPERVINO), and distributed throughout the nine cities with the greatest ovine populations: Canavieiras, Ilhéus, Itabuna, Ibicaraí, Itacaré, Uruçuca, Itapé, Itambé, and Macarani. All cities included in the study have a tropical climate with high and consistent rainfall throughout the year.

\section{Blood and milk sample collection}

Blood samples were collected from all lactating animals by puncturing the jugular vein. The sera were separated by centrifugation and stored at $-20^{\circ} \mathrm{C}$ until use. Milk samples of approximately $10 \mathrm{~mL}$ were collected by manual milking of the sheep teats. The samples were then packaged and stored at $-20^{\circ} \mathrm{C}$ until use. The study was approved by the Santa Cruz State University Ethics Committee for the Use of Animals (CEUA-UESC 031/09).

\section{Detection of antibodies}

Serum samples were tested for IgG antibodies against $T$. gondii by an indirect immunofluorescence test (IFAT) using F-7634-conjugated antibodies (Sigma-Aldrich, St. Louis, MO, USA) considering a 1:64 cut-off value (Guimarães et al., 2013). Negative and positive (1 x $10^{6}$ experimentally inoculated tachyzoites of the T. gondii RH strain in a 6-month-old sheep) control sera were used for all the slides. 


\section{DNA extraction from milk samples}

A 200- $\mu$ L aliquot of milk was used for DNA extraction using protocol number 8 from the Easy-DNA ${ }^{\circledR}$ Kit (Invitrogen, Carlsbad, CA, USA). After extraction, the DNA samples were quantified (NanoDrop, Thermo Scientific, Waltham, MA, USA), their purity checked (A260/A280), and their concentrations adjusted to $50 \mathrm{ng} / \mu \mathrm{L}$. The integrity of the DNA was evaluated on a $2 \%$ agarose gel stained with ethidium bromide $(0.5 \mu \mathrm{g} / \mathrm{mL})$. The DNA was stored at $-20^{\circ} \mathrm{C}$ pending subsequent polymerase chain reaction (PCR) analysis.

\section{T. gondii DNA amplification}

The T. gondii DNA within the isolated DNA samples was amplified using the method described by Homan et al. (2000). Tox4 (5'-CGC TGC AGG GAG GAA GAC GAA AGT TG-3') and Tox5 (5'-CGC TGC AGA CAC AGT GCA TCT GGA TT-3') were used as primers to amplify a 529-bp fragment from the $T$. gondii DNA. PCR was performed using $4 \mu \mathrm{L}$ extracted DNA added to a $21-\mu \mathrm{L}$ mixture containing $6.8 \mu \mathrm{L}$ ultrapure water, $6.0 \mu \mathrm{L}$ buffer for the Taq DNA Polymerase, $3.0 \mathrm{mM}$ of each primer, $1.0 \mathrm{mM}$ dNTPs, $1.0 \mathrm{mM} \mathrm{MgCl}$, and 0.2 $\mathrm{U}^{\text {Platinum }}{ }^{\circledR}$ Taq DNA polymerase (Invitrogen). The amplification of the parasite DNA was performed in a thermal cycler (Applied Biosystems, Foster City, CA, USA). The reaction consisted of 35 cycles with the following conditions: $5 \mathrm{~min}$ at $94^{\circ} \mathrm{C}$ for denaturation, followed by 35 cycles at $94^{\circ} \mathrm{C}$ for $1 \mathrm{~min}$ for denaturation, $1 \mathrm{~min}$ at $60^{\circ} \mathrm{C}$ for annealing, and $1 \mathrm{~min}$ at $72^{\circ} \mathrm{C}$ for extension, followed by a final extension step of $7 \mathrm{~min}$ at $72^{\circ} \mathrm{C}$. The products from each PCR were then subjected to electrophoresis on a $2 \%$ agarose gel, stained with ethidium bromide, and photodocumented. Tachyzoite DNA from the T. gondii RH strain was used as a positive control and ultra-pure water was used as a negative control.

\section{RESULTS}

T. gondii DNA was found in the milk samples of 6.5\% (18/275) of the animals and from $35.3 \%(6 / 17)$ of the estates. Antibodies against $T$. gondii were detected in $41.5 \%(114 / 275)$ of the animals, and all the estates had at least one animal with anti-T. gondii antibodies in its serum. In 38.9\% (7/18) of the animals whose milk samples tested positive for T. gondii DNA, the results of the serology tests were also positive. The distribution of DNA and IgG antibodies across the cities is presented in Table 1 .

\begin{tabular}{|c|c|c|}
\hline Cities $(\mathrm{N})$ & T. gondii PCR N/total (\%) & T. gondii IFAT N (\%) \\
\hline Canavieiras (15) & 0 & $1(6.7)$ \\
\hline Ibicaraí (17) & 0 & $7(41.2)$ \\
\hline Ilhéus (52) & $9 / 18(50)$ & $21(40.4)$ \\
\hline Itacaré (35) & $4 / 18(22.2)$ & $20(57.1)$ \\
\hline Itapé (35) & 0 & $6(17.1)$ \\
\hline Uruçuca (67) & $5 / 18(27.8)$ & $20(29.9)$ \\
\hline Itabuna (22) & 0 & $12(54.5)$ \\
\hline Itambé (23) & 0 & $20(87)$ \\
\hline Macarani (9) & 0 & $7(77.8)$ \\
\hline Total (275) & $18(6.5)$ & $114(41.5)$ \\
\hline
\end{tabular}




\section{DISCUSSION}

The prevalence of $T$. gondii that was determined in this study (6.5\%) was greater than that determined by Fusco et al. (2007) in Italy (3.4\%) and that determined by Camossi et al. (2011) in the Botucatu region, São Paulo State, Brazil (5.03\%). Although the results of the Brazilian study are similar to ours, the Botucatu region had a relatively low level (18.6\%) of anti- $T$. gondii antibodies in their tested sheep (Langoni et al., 2011), highlighting the fact that these animals might have been less exposed to the parasite than were those in Bahia. The microregion under current study has an extensive population of wild and domestic cats. The climatic characteristics, such as yearlong conditions of stable humidity, temperature, and precipitation, also contribute to the prevalence of $T$. gondii in this region as they are ideal for the parasite.

In the six estates that had animals that tested positive for the presence of $T$. gondii DNA, the owners reported the presence of a feline population, which was confirmed through observation during the collections. In addition, the breeding system found at these farms was extensive, allowing the animals to graze throughout the entire day. This might have increased the possibility of them having come into contact with oocysts of $T$. gondii, the main source of infection in sheep (Dubey, 2009).

The concurrent presence of anti-T. gondii IgG antibodies and the DNA of the protozoan in milk was observed in $38.9 \%(7 / 18)$ of the cases. Ovine females experience a fall in immunity during pregnancy (Roberts et al., 2001), mainly during their periparturient period, thereby allowing the reactivation of tissue cysts and the release of tachyzoites, which can lead to milk contamination (Camossi et al., 2011). IgG could be detected within 1-2 weeks after infection, with a peak between 1-2 months after infection; the IgGs persist lifelong at levels that decline gradually (Montoya, 2002). Hence, we believe that some animals that were seronegative despite the detection of $T$. gondii DNA in their milk $(61.1 \% ; 11 / 18)$ could have been in the early stages of infection, when their IgGs were not present at sufficiently high levels to be detectable by the test method used.

The excretion of $T$. gondii DNA in the milk of naturally infected sheep was verified in this study; however, parasite integrity and its infectious potential when it is present in milk have still not been extensively studied. To date, although some studies have been performed to establish an association between human clinical toxoplasmosis and the ingestion of goat's milk (Chiari and Neves, 1984; Jones et al., 2009), no such studies have been performed for sheep. In rural estates, particularly in the study area, milk is widely consumed in natura as a food source for families due to its high protein value, making it economically important (Camossi et al., 2011). Therefore, further investigation is required to assess the risk of human infection from consumption of the milk of infected sheep bred in these areas.

\section{Conflicts of interest}

The authors declare no conflict of interest.

\section{ACKNOWLEDGMENTS}

Research supported by Fundação de Amparo à Pesquisa do Estado da Bahia (FAPESB - \#APP0001/2009) and Coordenação de Aperfeiçoamento de Pessoal de Nível Superior (CAPES). 


\section{REFERENCES}

Bezerra RA, Carvalho FS, Guimarães LA, Rocha DS, et al. (2012). Genetic characterization of Toxoplasma gondii isolates from pigs intended for human consumption in Brazil. Vet. Parasitol. 189: 153-161.

Bresciani KDS, Toniollo GH, da Costa AJ, Sabatini GA, et al. (2001). Clinical, parasitological and obstetric observations in pregnant bitches with experimental toxoplasmosis. Cienc. Rur. 31: 1039-1043.

Buxton D, Maley SW, Wright SE, Rodger S, et al. (2007). Toxoplasma gondii and ovine toxoplasmosis: new aspects of an old story. Vet. Parasitol. 149: 25-88.

Camossi LG, Greca-Júnior H, Corrêa AP, Richini-Pereira VB, et al. (2011). Detection of Toxoplasma gondii DNA in the milk of naturally infected ewes. Vet. Parasitol. 177: 256-261.

Chiari CA and Neves DP (1984). Toxoplasmose humana adquirida através da ingestão de leite de cabra. Mem. Inst. Oswaldo Cruz 79: 337-340.

Costa VM and Langoni H (2010). Detection of Toxoplasma gondii in the milk experimentally infected Wistar female rats. J. Venom. Anim. Tox. Incl. Tropic. Dis. 16: 368-374.

de Oliveira LN, Costa LM Jr, de Melo CF, Ramos Silva JC, et al. (2009). Toxoplasma gondii isolates from free-range chickens from the northeast region of Brazil. J. Parasitol. 95: 235-237.

Dubey JP (1998). Advances in the life cycle of Toxoplasma gondii. Int. J. Parasitol. 28: 1019-1024.

Dubey JP (2009). Toxoplasmosis in sheep - The last 20 years. Vet. Parasitol. 163: 1-14.

Edwards JF and Dubey JP (2013). Toxoplasma gondii abortion storm in sheep on a Texas farm and isolation of mouse virulent atypical genotype T. gondii from an aborted lamb from a chronically infected ewe. Vet. Parasitol. 192: 129-136.

Fajardo HV, D'ávila S, Bastos RR, Cyrino CD, et al. (2013). Seroprevalence and risk factors of toxoplasmosis in cattle from extensive and semi-intensive rearing systems at Zona da Mata, Minas Gerais State, Southern Brazil. Parasit. Vectors 6: 191.

Fusco G, Rinaldi L, Guarino A, Proroga YT, et al. (2007). Toxoplasma gondii in sheep from the Campania region (Italy). Vet. Parasitol. 149: 271-274.

Guimarães LA, Bezerra RA, Rocha de S and Albuquerque GR (2013). Prevalence and risk factors associated with antiToxoplasma gondii antibodies in sheep from Bahia state, Brazil. Rev. Bras. Parasitol. Vet. 22: 220-224.

Homan WL, Vercammen M, de Braekeleer J and Verschueren H (2000). Identification of a 200 to 300 fold repetitive 529 bp DNA fragment in Toxoplasma gondii, and its use for diagnostic and quantitative PCR. Int. J. Parasitol. 30: 69-75.

Ishag MY, Magzoub E and Majid M (2006). Detection of Toxoplasma gondii in the milk of experimentally infected lactating she-camels. J. Anim. Vet. Adv. 5: 456-458.

Jones JL, Dargelas V, Roberts J, Press C, et al (2009). Risk factors for Toxoplasma gondii infection in the United States. Clin. Infect. Dis. 49: 878-884.

Langoni H, Greca H Jr, Guimarães FF, Ullmann LS, et al. (2011). Serological profile of Toxoplasma gondii and Neospora caninum infection in commercial sheep from São Paulo State, Brazil. Vet. Parasitol. 177: 50-54.

Montoya JG (2002). Laboratory diagnosis of Toxoplasma gondii infection and toxoplasmosis. J. Infect. Dis. 185: S73-S82.

Pereira-Bueno J, Quintanilla-Gozalo A, Pèrez-Pèrez V, Álvarez-García G, et al. (2004). Evaluation of ovine abortion associated with Toxoplasma gondii in Spain by different diagnostic techniques. Vet. Parasitol. 121: 33-43.

Powell CC, Brewer M and Lappin MR (2001). Detection of Toxoplasma gondii in the milk of experimentally infected lactating cats. Vet. Parasitol. 102: 29-33.

Ragozo AMA, Yai LEO, Oliveira LN, Dias RA, et al. (2009). Isolation of Toxoplasma gondii from goats from Brazil. $J$. Parasitol. 95: 323-326.

Roberts CW, Walker W and Alexander J (2001). Sex-associated hormones and immunity to protozoan parasites. Clin. Microbiol. Rev. 14: 476-488.

Vitor RWA, Pinto JB and Chiari CA (1991). Toxoplasma gondii elimination in urine, saliva and milk of experimentally infected goats. Arq. Bras. Med. Vet. Zootec. 43: 147-154. 